\title{
1
}

\section{Introduction: Imagining Alternatives to Globalization of the Nation Form}

\author{
Irfan Ahmad and Jie Kang
}

Anthropology is the discipline that studies understandings of the world that differ from this ideology [of the modern West] and by that token offers an ideological critique.

—Peter van der Veer (2016: 153)

Can we retain the methodological rigor of modern social science while restoring some of the prestige and energy of earlier visions of scholarship, in which moral and political concerns were central?

-Arjun Appadurai (1997: 7)

I. Ahmad $(\bowtie)$

Department of Sociology, Ibn Haldun University, Istanbul, Turkey e-mail: irfan.ahmad@ihu.edu.tr

J. Kang

Max Planck Institute for the Study of Religious and Ethnic Diversity, Göttingen, Germany e-mail: kang@mmg.mpg.de 


\section{The Arguments}

The aims of this chapter revolve around three arguments. First, in agreement with the contributions this volume consists of, it demonstrates the continuing force and reality of the nation form as the only mode of politics worldwide currently. Against arguments seeing the demise of nationalism as integral to the march to globalization, globalism or a cosmopolitan future on the one hand and its persistence regardless of globalization on the other, ${ }^{1}$ it argues that what characterizes the world is the 'globalization of nationalism' (Greenfeld 2016a, b). This globalization has been such that the national seems to substitute as well as prostitute the rational. The responses to COVID-19-in the form of the stories told about its origin, the groups blamed for its spread, the conspiracy theories that surround it, the ways to fight the virus, the competition between nation states to make or procure its vaccine and the increasing aggrandizement of the state power-amply show not only the persistence of nationalism but also its fierce intensification. Indeed, a new term, vaccine nationalism, is now in use by the media, social scientists, health experts and others. ${ }^{2}$ However, it seems not to have occurred to anyone that the time has arrived to vaccinate nationalism itself.

The absence of calls to vaccinate nationalism indexes a broader tendency, including among anthropologists, to regard nationalism as 'natural.' This is baffling. In the anthropological literature on institutions from the band through the tribe and chiefdom to the nation state (Eriksen 2001; Harris 1991; Kottack 2008; Skalnik 1983), the time given to the nation state is too short, equivalent not even to a week within a period of a hundred years (to put it quantitatively). Integral to this tendency is a scarcity of interrogation of the violence that nation states have directly or indirectly unleashed throughout the twentieth and current centuries. This interrogation, pertaining to the efficacy and morality of nationalism as a form of polis, constitutes the second argument. To those who may take it as a normative position outside the 'facts on the ground,' we submit that to shun moral concerns is to dwarf intellectual pursuits. Long ago, C. Wright Mills (1959: 55) warned about the danger of scholars becoming technicians. To think what is moral rather than ceaselessly analyse what barely exists and is real was indeed a key task before the relatively recent rise of a 'value-free' science associated with Max Weber (Allen 2004). Here it is important to note Cynthia Weber's (2010) arresting 
internal critique of International Relations (IR) as a discipline, whose still-dominant 'realist' school claims to ground itself in 'reality.' In contrast, Cynthia Weber shows how realism is itself based on fiction. Contrary to its own claim, moreover, the fiction has a tacit normative assumption like the orientation to 'induction' or 'fact' in British social anthropology (Kuper 1983; Parkin 2007). As its founding figure, however, Malinowski's theory of culture, based on a hierarchy of needs, is far from inductive (Ahmad 2021a). It is one thing to observe 'facts' with an open mind, but quite another to presuppose a blank mind, which simply does not exist.

Tellingly, the epigraph from Peter van der Veer's book placed at the beginning of this chapter sees anthropology's goal as studying neither 'reality' nor 'facts'; rather, it is to study 'understandings' of the world. Furthermore, this aim is aligned with anthropology as a comparative craft. Deploying this productively recast vision of anthropology gains further salience vis-à-vis the second argument. Though not always broached explicitly, along with its entwining with religion, at the core of van der Veer's life-long expositions of nationalism has been the latter's trajectory marked with multiple exclusions: racial, ethnic, linguistic, religious, economic and so on. Importantly, this trajectory is enmeshed in the bloodshed, unspeakable dehumanization and violent displacement evident in the figures of refugees and asylum-seekers being 'processed' as statistical and securitized objects by plutocratic-democratic states from North America, Europe and the Manus Islands in the Pacific to India. Van der Veer's terse Afterword (also see Ahmad and van der Veer, this volume) offers a glimpse of the history of nationalism as vicious. As this volume is a Festschrift produced by his doctoral students to honour van der Veer's rich, probing and consensus-defiant scholarship, which has variously guided our own respective work, it would only be a fitting critical tribute if we were to extend and expand it.

To do so is to ask questions that van der Veer's impressive corpus of scholarship, spanning over three decades and covering such diverse political formations as India, China and the modern West (including his country of birth, the Netherlands) has not overtly pursued but still require answers (see Ahmad, this volume). Should scholars not imagine alternatives to the nation as a mode of living (ergo, dying/killing)? In such hard work of the imagination, what relationship coheres the past, present and future? How does this relationship shape religion as well as being shaped 
by it? Is thinking about such alternatives possible without distancing inquiries from the very nationalism that generate and regulate them? If so, does it vary from one inquiry to another? This set of questions constitutes the third argument. It begins by showing how, in certain of their writings, philosophers like Richard Rorty and Jürgen Habermas at once presuppose, analyse and sign nationalism. Opposed to this stance, the next section dwells on writings by anthropologist-social theorist Arjun Appadurai, who problematizes nationalism in order to think beyond it. Discussing the issue of the Caliphate, it ends with an alternative to nationalism that is different from Appadurai's, the source of which is present. Outlining opposition to nationalism in the thoughts of Muhammad Iqbal (1877-1938), poet-philosopher of undivided India, and Hasan al-Banna (1906-1949), founder of Egypt's Young Men's Muslim Association and Muslim Brotherhood, we are interested in the pre-World War II (pre-WWII) imagination of a non-national form of polis.

The third argument becomes clearer when it is juxtaposed to influential notions of anthropology. Justly uneasy about anthropology's declining public voice, Herzfeld (2018: 133) locates the reason for it in its indifference to 'reality,' hence his plea that 'anthropology is a realist discipline!' Earlier, Malinowski (1945: 3) presented a similar idea; in his presentist notion of anthropology, 'the man of science has to study what is, and not what might have been' (italics author's). Contra Malinowski, 'what might have been' indeed ought to be central to anthropology. From the prism of decolonized knowledge and anthropology, ${ }^{3}$ merely to oppose good to bad, inclusive to exclusive, civic to ethnic nationalism is insufficient. A critique qua critique does not simply replace a negative adjective with positive one while retaining the sanctity of what comes after, that is, the nation form. A move away from colonization must examine the universalized wing of its politics: the nation state. If the nation state is integral to colonialism, only adjusting the former will betray decolonization. Here Fanon (1963) is salutary in criticizing nationalism. His The Wretched of the Earth is unsparing in its attack on bourgeois nationalism and in seeing the national bourgeoisie as a conduit of capitalism, hence in cahoots with neocolonialism. Yet, Fanon could not escape the nation form either. For Lazarus (1993: 71-72; italics in original), 'Fanon's 
critique of bourgeois nationalist ideology was itself delivered from an alternative nationalist standpoint.'

The next four sections illustrate these arguments in the order set out above. For structural coherence, the third argument is divided into two sections. The Introduction ends with an outline of the chapters to come. Much of the anthropological literature on nationalism has not made these arguments, certainly not in the ways formulated and substantiated here. ${ }^{4}$ The claim to their 'novelty' rests on the premise that however novel an idea it is, it comes from somewhere rather than nowhere. And the novelty or otherwise of an argument finds its bearing only within a paradigm (Hallaq 2018). To clarify, the Introduction's three arguments are mostly independent of the chapters. It is our hope, however, that the questions raised and arguments made here will advance and enrich future anthropological and other works.

\section{National Borders in the Time of a Borderless Virus}

If evidence of nationalism's persistence were wanting, responses to COVID-19 have furnished plenty. Many nation states nationalized the virus. Donald Trump baptized it as a 'Chinese' virus. Beyond the liberalconservative divide, nationalization of the virus and viral nationalization occurred, and in some cases with deadly results. Chinese individuals were attacked physically and verbally across the continents and in the US, Europe, Oceania and India. In France, tweets inciting violence against the Chinese were posted, accusing them of being responsible for undermining the freedom of 'real French' people in the lockdown. In India, people who looked Chinese were attacked and spat on. Abusively called 'Chinki,' they were 'blamed for bringing Covid-19 to India' (Ahmad 2020a; Krishnan 2020; Liu 2020; Theise 2021).

The nationalization of the virus continued from its origin to its spread. In Britain, India, Italy and the US, Muslims were blamed for spreading it. Sergio Benvenuto, an Italian psychoanalyst, wrote how certain his domestic servant was that Arab Muslims had 'schemed' the coronavirus. 
In Britain, far-right groups blamed Muslims for its spread. In the US too, the media gave it a Muslim angle, urging people 'to think about this [virus] the same way we think about terrorism and 9/11.' In India, the media spun the narrative that Muslims were deliberately spreading the virus. 'CoronaJihad' trended on Twitter. The official discourse only bolstered the media narrative, particularly about the Tablighi Jamaat (TJ), a non-political group urging Muslims to practice Islamic rituals. In its news bulletin about the coronavirus, the Delhi government put out a separate column, called 'Markaz Masjid [the headquarters of TJ],' to which it causally linked cases of infection. There were also rumours about how Muslims were 'spitting on food and infecting water supplies with the virus.' Images of Muslims as spreaders of the virus even figured in a film that ostensibly contested the politics of enmity that had been unleashed during the lockdown. A short film, Darr (Fear), spread that politics in the guise of bringing 'harmony between communities.' Its message was that not all Muslims should be blamed because only some Muslim vendors had spat on vegetables to spread coronavirus. That some Muslim vendors had done this was taken as truth and broadcast on social media (Ahmad 2020a). In contrast, in April 2021, at the peak of the second wave when daily cases of infection were exceeding the hundred thousand mark, 3 million Hindus gathered freely in Haridwar for the Hindu ritual of Maha Kumbh Mela. Rather than stop this massive gathering, both government and media supported it (Sikander 2021; Sen 2021). There was no pretence about ensuring public health. ${ }^{5}$

If the Indian case illustrated the idea of the nation's enemy already being within its borders, ${ }^{6}$ old national borders were reactivated and new ones erected in the heart of the European Union (EU), viewed by Habermas (2003: 94) as an 'example for a form of democracy beyond the nation-state' and as an insignia of a 'cosmopolitan' future. Spain imposed a two-week quarantine for all arrivals from the Schengen free-travel zone (the Schengen treaty was made in 1985 and came into force in 1995). In retaliation, France imposed the same rule for people entering its own territory from Spain. While Denmark reopened its borders with Germany, it did not do the same with Sweden even though infection rates in parts of Sweden were lower than in some parts of Denmark (Alemanno 2020). In March, Germany sealed off its borders with Switzerland and France 
(Roache 2021), as it did with parts of Austria and the Czech Republic, whose citizens the police prevented from entering Germany ( $D W$ News 2021). While old borders were activated, new national fences also emerged. Before the pandemic, people from Konstanz and Kreuzlingen, municipalities in Germany and Switzerland respectively, freely moved between them. To fight the virus, in April the Swiss authorities erected a fence between them. Notwithstanding the fence, lovers from both sides met, conversing with one another through holes in the fence (see Fig. 1.1). To stop romantic touches, including exchanges of things, the authorities later erected another fence one and a half metres in front of the first one. In a photo essay in Time, there was a touching vignette about an eightyyear-old grandmother suffering from cancer. While visiting her, her grandson, the German photographer, Ingmar Nolting, lamented that he

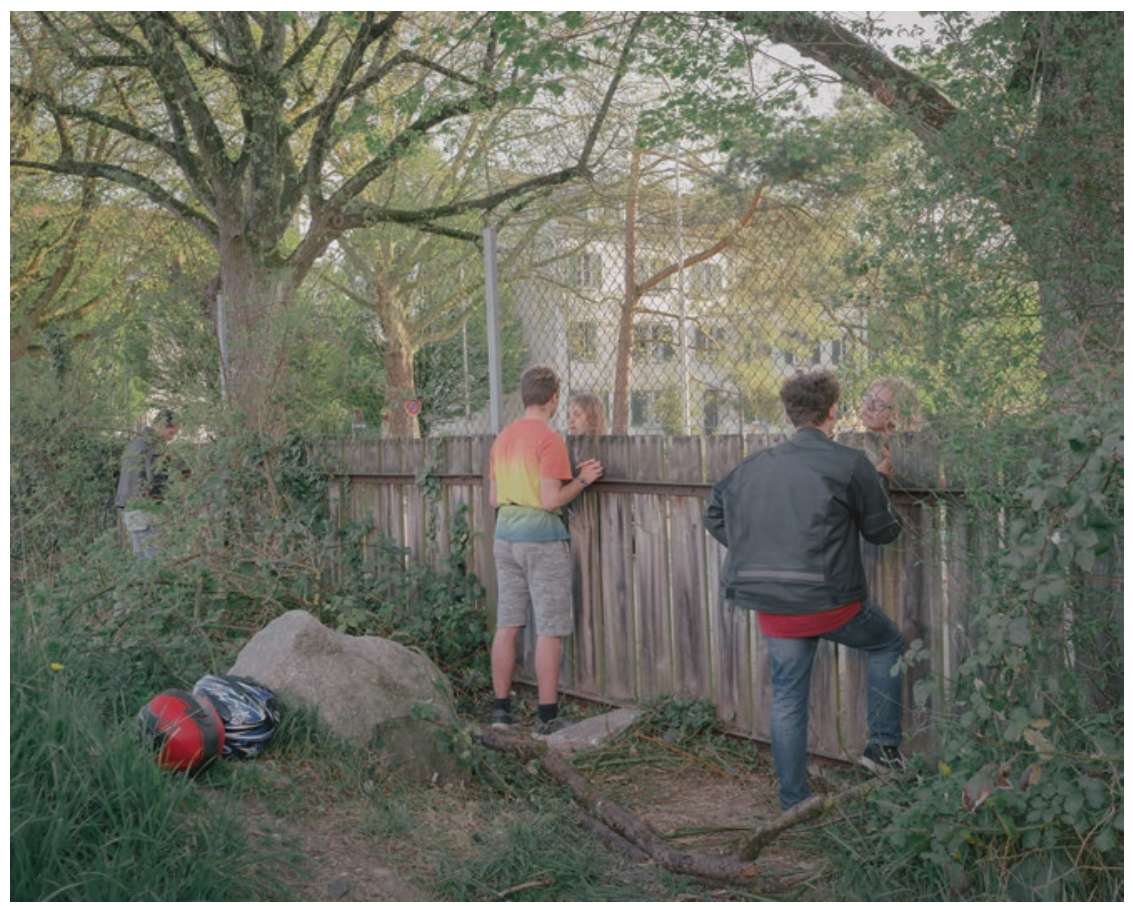

Fig. 1.1 Lovers in conversation at the new fence built on the Swiss-German border during the 2020 lockdown. (Photo: Ingmar Björn Nolting) 
could not hug her. His grandmother, whose doorway had the message 'I'm staying at home' stuck to it, said: 'Everyone must stick together and do their part to keep Germany stable' (Roache 2021). It is hard not to notice the intimacy between filial and national love here.

Along with the erection of national fences and the hardening of existing ones, vaccine science itself became 'nationalistic' (Gebrekidan and Apuzzo 2021). So intense was the nationalist impetus that a proposal to make vaccine a global good was blocked. Ghana, Pakistan, South Africa and others had called for a free 'people's vaccine,' but the US, EU and other powers thwarted it. The reason was not just the desire for profiteering by pharmaceutical companies in a 'free' economy. Many states, the US included, had in fact poured a lot of cash into funding the companies involved in it. If they wanted, these states could have made companies produce the people's vaccine. That the rich and Western states blocked the proposal in the name of 'innovation,' protection of intellectual property and patents (ibid.) shows, to invoke Karl Polanyi (1944: 147), that 'laissez-faire was planned.' It also belies the slogans of borderless globalization and caring for humanity. What could be more global than the concrete proposal for the people's vaccine against a borderless global virus and its access to all across the globe? Here the German philosopher Peter Sloterdijk (2012: 188) seems both right and wrong. He is right to say that 'people in the West are the only ones who speak of globalization, for all others the theme doesn't exist.' He is wrong because the leaders of Ghana, Pakistan and South Africa did speak of globalization, though its content differed radically from that of Western leaders. Sloterdijk perhaps meant globalization and globalism as an ideological project, which, as sociologist Manfred Steger $(2005,2009)$ notes, is driven by Western elites under the aegis of US military power. Due exactly to this, apologists for globalization like Thomas Friedman present it as a truth that no one is 'in charge of' globalization (in Steger 2005: 36; also see Fernandez 2011).

The annihilation of the people's vaccine proposal went hand in hand with escalation of the state of exception. In the name of fighting coronavirus, Viktor Orban in Hungary practically became a dictator. The Hungarian Parliament allowed him to rule as long as he himself deemed it necessary. Surveillance by states and companies and crackdowns on media and activists increased in Bangladesh, Ghana, India, Kenya and Sri 
Lanka. In India, among those jailed were two research scholar-activists of Jamia Millia Islamia, a university in Delhi (Ahmad 2020a). In short, the escalation of the state of exception in the name of security and the nation-(semi)democratic, communist, undemocratic or a combination thereof-took place globally.

\section{On Vaccinating Nationalism, or the Nexus Between Violence and Nationalism}

The erection of fences dividing lovers at the Swiss-German border in 2020 may appear as new, especially after the fall of the Berlin Wall following the end of the Cold War, the onset of a 'borderless world,' 'deterritorialization' and so on (Appadurai 1996a). It is not. Indeed, more nation-state borders exist today than in 1989. In the past decade, EU states committed to free movement within have built lethal border walls to stop 'immigrants' from without. Along its borders with Serbia and Croatia, Hungary built a thirteen-foot high wall with razor wire (Donnan et al. 2018). Beyond Europe, the dawn of the new century saw billions of dollars spent in building thousands of kilometres of border walls. India (the largest democracy), Israel (the most stable democracy in the Middle East) and the US (the oldest democracy) together built gigantic national walls of 5700 kilometres long (Jones 2012). ${ }^{7}$ Historically, most borders across the world were born out of violence and in turn continue and signify violence-literal, symbolic, social-cultural and infrastructural. In cases where there is 'peace' along the borders, violence is only deferred, and peace itself is kept through violence. ${ }^{8}$ In Europe, after the long religious war, theoreticians concluded that the solution to war within was its displacement without. In Reinhart Koselleck's (1988: 44) view, this theorization was enabled by divorcing morality from politics and the resultant notion of 'justus hostis, a rightful enemy.' In matters of war and peace in the age of nation states, such are the relations between inside and outside, within and without, here and there! The stage is set to execute the second argument: nationalism's relations with violence and destruction. 
In largely the anthropological and sociological literature, there are two main positions. While one holds that nationalism is war-prone, the other disagrees. There is also a third position, which it is difficult to name. While the brutality of WWII was still continuing, Malinowski (1941: 537, 540) published a long, largely incoherent essay. Rightly refuting biological explanations for war, however, he also viewed it as productive: 'Warfare of this type is culturally productive in that it creates a new institution, the nation-state.' In his anthropology of war, the conquest of the New World was positive: 'The most important cultural effect of conquest is an all-round enrichment in national life through a natural division of function between conquerors and conquered.' Notice that to Malinowski, the division of function between conquerors and conquered was 'natural,' not coercive and political.

To return to the first position, drawing on the world's datasets over the past two centuries, Andreas Wimmer (2013: 23, 141) argues that the 'nation-state model is a major cause of war in the modern world.' Between 1816 and 2001 there were 484 wars, of which 77 were wars of conquest, 111 were wars between states and 296 civil wars. He established empirically that formations of empire and nation states are 'two important sources of war in the modern world.' Earlier, Cederman et al. (2010: 114) argued that about half the conflicts since WWII were linked to ethnopolitical fights over state power.

One strand of this literature iterates that the passion to kill and be killed is central to nationalism. Carolyn Marvin and David Ingle (1999) maintain that the notion of the totem has shifted from pre-modern society to the totem of the modern nation state. They equate the nation, its rituals and calls for bodily sacrifice, memorialization and the sacredness of flags with the salience of religious rituals in traditional societies. The sacralization of the nation state as a deity entails that its members be ready to sacrifice themselves for its upkeep and renewal. Religion is the core of this sacrificial urge. Later Marvin (2002: 21, 28) criticized Robert Bellah's concept of civil religion as 'a poor ... pretender to religion.' Though not taken as sacred, civil religion, he held, 'inherits the rituals and symbols of Christianity.' Bruce Kapferer (1988: 6) made a similar argument in his study of Sinhalese Buddhist nationalism in Sri Lanka and Anzac nationalism in Australia. He argued that 'the violence, 
destruction, and prejudice of Sinhalese and Australian nationalisms' are derived from the 'force of Buddhist and Christian themes ... [and] formed and realized in the religious order of nationalism itself.' With a focus on the imbrication of Hindu nationalism with religious rituals and sacred spaces, van der Veer $(1994,1996)$ has forcefully argued how nationalism and violence are intertwined in India, impacting the everyday as well as the extraordinary.

Rejecting the 'nationalism is war-prone' thesis, John Hutchinson argues that 'many wars may have a nationalist character, but this does not entail that nationalism was their cause.' To Hutchinson, 'strong nation states' can stem political violence. Criticizing Wimmer, and noting the presence of conflict in the non-West, Hutchinson asks: 'In what sense postcolonial states can be characterized as nation-states, and how genuine is the nationalism proclaimed by the political actors' $(2017: 161,184)$. Note that this is not a politician vouching for nationalism's genuineness but a scholar. Like Hutchinson, Siniša Malešević (2013: 13) rejects any 'natural linkage' between nationalism and violence. In the Introduction to their edited volume, Nationalism and War, John Hall and Malešević question the view that 'nationalism causes war.' Presenting a 'complex picture,' they stress the nature of imperial legacies, types of regime, geopolitical conditions and other factors. They observe that while there was 'some causal relationship' between nationalism and war in 1914, there was a 'total connection' in 1939. Writing from a Eurocentric worldview, they hold that the marriage between nationalism and imperialism is now void, 'at least in Europe.' Since wars were linked to the desire for 'coherence and size,' and as this desire is absent in the present, 'the great states,' they predict, 'will manage their nations with tolerance' (Hall and Malešević 2013: 23). Although they don't specify what 'the great states' are, the context suggests they mean the Great Powers. How did the national coherence of the Great Powers, then, come about?

Taking Spain, France and England as case studies, political scientisthistorian Anthony Marx (2003: ix, 200, 3) examines the views of Westerners who 'enjoy self-congratulation' in depicting their own nationalism as liberal, inclusive, tolerant and engage in the 'denigration of others,' whose nationalism is often viewed as illiberal and exclusive. Tracing the history of European nationalism back two centuries earlier than the 
usual accounts, he argues: 'At the heart of liberalism is an ugly secret: supposedly inclusive nationalism was founded on the basis of violent exclusion, used to bound and forge nation to whom rights would then be selectively granted.' Instructively, Marx begins his Introduction with 1492 when 'Christian forces' took control of Granada and expulsion of Jews and Muslims followed. In his account, 'religious unity' and 'linguistic homogeneity' were thus crucial to nationalism.

To return to Hall and Malešević, they are silent about the constitutive relation among 'the great states' and their implied opposite, 'the weak states.' For them, the violent asymmetrical make-up of the world of nation states and the exercise of power, at times simply brutal, by some nation states against others is unimportant because 'the age of the empire is over.' Really? Not for Derek Gregory (2004), who sees its continuation at work, for instance, after 9/11, and not only in Afghanistan, Iraq and Palestine but elsewhere too. Neither Hall and Malešević nor Hutchinson say anything substantial about nationalism and violence in the new century. Barring a passing mention of terrorism, nor do they dwell on nationalism and the Global War on Terror (GWOT), the duration of which is already three times longer than that of WWII, the destruction it caused not being over. According to the 2019 Costs of War project led by Neta Crawford and anthropologist Catherine Lutz (2019), at least 800,000 have died directly due to the war. In another estimate, in 2018 the number of people killed was already over 1 million (Dunning and Doyle 2018). As for refugees, from Afghanistan, Iraq, Pakistan and Syria alone, they numbered 21 million (Crawford and Lutz 2019).

Devotees to nationalism-among them are also scholars-may dismiss the above figures as unrelated to nationalism. The standard account of a million people killed due to GWOT states that the killings were due to 'terrorism,' 'internal sectarian' divides and failed states in the Middle East. In another shade of such explanations, Islam itself becomes the factor. But is terrorism unhooked from nationalism? Taking Burma, India and Sri Lanka as case studies, Ahmad (2021a) shows how the problem of terrorism is rooted in the purificatory, unifying project of nationalism in each of the three nation states. He extends this argument beyond the subcontinent to explain the phenomenon of terrorism in most places, including those in and directed against the West. The long and 
continuing racist assaults on black lives from the time of the Ku Klux Klan to the 2021 raid by the white Christian nationalists on Capitol Hill—as well as the resistance to it_-pertain squarely to nationalism. The reason why, in most accounts, the deeper connections between terrorism and nationalism, like those between racism and nationalism, are rarely systematically pursued is because to do so would mean questioning the very system of nation states that Western elites have built and in which most non-Western states enviously participate. Nationalism's connections with violence logically extend to the phenomenon of immigration. Anthony Smith (2007: 27), a known nationalism scholar, puts it as follows: 'If war was formerly the focus of and 'test' of nations, today it is immigration that fulfils that function.' That the immigrants Smith was referring to are predominantly Muslims is too obvious to require stating (TEDx Talks 2020). ${ }^{9}$ Anthropologist Banu Karaca (2021: 16) notes that, post-9/11, immigrant and Muslim became interchangeable terms in Germany.

\section{Studying Nationalism, or Signing It?}

To protect nationalism analytically rather than radically expose it to public scrutiny to discuss its limits and violence is a symptom of a deeprooted fear-the fear of searching past the present for an alternative polis. In her passing but arresting remark, Erika Harris (2016: 246), an expert on nationalism in Central Europe, notes that this lack of an alternative has created 'a near existential anxiety.' In our view, it is the other way around. Since this unelaborated quote from Harris occurs only in her final paragraph, we pursue her allusion differently. Greenfeld (2016a: 118) views nationalism and functional mental illness like schizophrenia, affective disorder and depression as interconnected, arguing that 'only with nationalism functional mental disease became a social problem and an issue in public health.' If correct, could it be that manic depression, born out of very nationalism, is a cause of the absence of sustained thinking about alternatives to nationalism? This conjecture rests on the ground that, like hopelessness, depression precludes thinking about hopeful alternative futures. ${ }^{10}$ Concurrent with and bequeathed by Western 
modernity, however, both nationalism and mental illness came to be seen as universally 'natural.' To de-naturalize them is to begin to imagine alternatives to nation states, a task completed in the section ahead.

First, there is the question of how nationalism also informs and thrives in academic writings. To this end, we do not discuss past theorists like Émile Durkheim (d. 1917) and Max Weber (d. 1920) who, during WWI, supported their respective nation states-Weber backed Germany for the cause of Kultur, whereas Durkheim supported France 'with equal vehemence' to defend 'the cause of civilization' (MacIntyre 1984: 3). Our focus instead is contemporary. Greenfeld (2016b: xxii; italics author's), cited earlier, writes: The Japanese 'never wanted to be "like" the West' and 'conscious of being unlike, they did not envy us and did not develop ressentiment.' The Them versus $U s$ dichotomy at the heart of nationalism also occurs, albeit differently, in texts like Greenfeld's, a sociologist. Nationalism also structures the writings of 'universal' philosophers like Richard Rorty (d. 2007) and Habermas (b. 1929).

The nationalism of Rorty, a pragmatist American philosopher, is manifest in many works, including Achieving Our Country, a text proclaiming 'national pride' (1998: 3). Elsewhere he wrote: 'My native country has world-historical importance only because it cast itself in the role of vanguard of a global egalitarian utopia' (Rorty 1999: 234). Shunning any humility, he continued: 'I think that our country ... is an example of the best kind of society so far invented' (in Billig 1993: 78). Needless to add that Rorty's best society resembled the US as a nation state. Clearly, Rorty's national pride partakes in the wider Western discourse. He also addressed himself as 'we Western liberals.' Michael Billig reads his nationalism as part of the Pax Americana in which the American voice becomes the voice of 'us all.' Rorty's defence of democracy was likewise nationalist in that it was actualized in a nation, the US, which in turn was taken as the motor of democracy. Did his defence of democracy extend to democracy everywhere? Probably not! As he put it, 'we postmodern bourgeois liberals' should 'defend the institutions ... of the rich North Atlantic democracies' (in Billig 1993: 78).

How does nationalism work in Habermas, an influential contemporary philosopher engaged in 'defending the project of modernity and universalism' (Chambers 1996: 13)? In his 2003 text, at once an analysis and 
an appeal, on the mass demonstrations against the US-led invasion of Iraq, Habermas amply displayed his sense of nationalism (Habermas and Derrida 2003: 291, 293). ${ }^{11}$ To counter 'the hegemonic unilateralism of the United States,' he proposed a common European policy. To the existing and future members of the EU, he advised adding a 'European dimension' to their 'national identities.' The core of this European identity, Habermas observes, is the distinct 'form of spirit' 'rooted in the Judeo-Christian tradition.' Striking is the syntagma 'Judeo-Christian tradition,' a post-WWII American coining absent in the pre-Holocaust vocabulary (Sorkin 2015: 121-122). Without telling his readers about the term's radical novelty, Habermas notes that democracy, individualism, rationalism and so on, which were bequeathed by this tradition, later spread to the US, Australia and elsewhere. ${ }^{12}$ So infused with Eurocentrism was Habermas' appeal that at the very far end he had to say that he did not favour Eurocentrism. The political theorist Iris Young (2003), however, noted how Habermas' appeal amounted to a re-centring of Europe that was far removed from global democracy. Calling his posturing of Europe against the US as 'little more than sibling rivalry,' she pointed out how his appeal to fashion 'a particularist European identity' meant designing the 'other.' Young also identified the erasure of protests outside Europe, for Habermas highlighted only those in Europe to mark 'the birth of a European public sphere.'

In many ways, the elements of a European identity which Habermas advocates resonate with discourses pursued aggressively by Geert Wilders and Marine Le Pen, anti-Muslim radical populists of the Netherlands and France respectively. Both differently mobilize the 'Judeo-Christian' identity of Europe/the West to fashion Islam as the enemy (Morieson 2021). This discursive commonality is also manifest in the silencing of Muslim voices. If the traditions and values of the people against whom the war was waged and on whose behalf he seemed to speak appear as invisible in Habermas' 'cosmopolitan' text, in the discourses of Wilders and Le Pen Muslim voices are muffled as the reverse of Dutch, French or Western 'Judeo-Christian' identities. It is worth recalling that in 1991, in the name of universal principles and a universal constitution, Habermas had supported the war against Iraq, ignoring 'the rationalization of the violence and barbarism of the constitutional orders themselves' (Hill and 
Montag 2000: 7). ${ }^{13}$ To clarify, our point is not that Habermas, Wilders and Le Pen are alike. Yet, a fair assessment cannot bypass the shared ground to construe them hastily as chalk and cheese.

Furthermore, if taming nationalist zeal among formerly hostile countries under the banner of the EU is cosmopolitanism, as Habermas suggests, it is neither novel nor universal. August Schlegel (d. 1845) was a German nationalist wedded to 'European patriotism' (in Ahmad 2013: 239). He imagined a united Europe, observing: 'If I might make a claim on the German feeling of nationalism, it would be ... to recognize itself as the motherland of Europe.' Giving this primacy to both Germany and Europe was also religious. To his brother Fredrick Schlegel, though born in Orient, Christianity 'expressed its most essential and outstanding effects wholly in the Occident' (in Murti 2001: 16, 13). Unlike Schlegel and others, Habermas separates patriotism and nationalism through 'constitutional patriotism.' This task is undertaken to move away from Germany’s Nazi-era nationalism (Habermas 1998; Müller and Scheppele 2008) and 'combine universal principles of democracy and personal liberties in the constitution of a single country' (Turner 2004: 286). However, is it conceptually possible to delink nationalism from patriotism? Alasdair MacIntyre (1984: 14) thinks not. He takes patriotism as 'a permanent source of moral danger.' ${ }^{\text {' }}$ Describing fanaticism as 'patriotism for religion,' Muhammad Iqbal, whom we shall meet later, regarded patriotism as 'fanaticism for the country' (in Ahmad 2019: 1). Notably, Habermas' legal patriotism is both derived from and devoted to the Western project, for he firmly stated: 'the only sort of patriotism that will not alienate us from the West is constitutional patriotism' (in Rorty 1998: 145n11). Our italicization of us and from the West should be noted.

Central to constitutional patriotism is loyalty to the constitution, itself a territorial-national text the words of which can be, indeed they have been, stretched, skewed, molested or made still. Despite both countries' constitutional pledges to socialism, ruthless capitalism is ongoing in India and China, as is violence against Muslims, regardless of their both being constitutionally secular (see Ahmad and van der Veer, this volume). Apt here is Joshua Mitchell's (2008: 5) remark that 'with loyalty comes cruelty as well.' After all, nation states kill citizens for committing treason. From the frame of the nation, Habermas' festive story of individualism 
(above) is misleading. ${ }^{15}$ As an individual, when the novelist E.M. Forster (d. 1970) stated that 'he would betray his country [rather] than his friends, he was met with contumely' (Smart 1998: 84). In his autobiography, Ghaus Ansari (1929-2012), an Indian anthropologist trained in Austria and the UK, noted the nefarious charges of national disloyalty made against him (Ahmad 2018).

It is obvious that Habermas' Eurocentric nationalist claim of 'democracy beyond the nation state' does not include democracies like India or Senegal. That for non-Europeans the EU's cosmopolitanism is for Europeans alone (that too for not all beyond race, religion or class) and is ultimately nation-statist is evident from its visa procedures. NonWesterners apply for visa to one of Europe's nation states, not to the nonexistent EU embassy. The reason why the philosophical nationalism of Habermas passes as universal and cosmopolitan is not only a matter of individual accomplishment. Rather, it is because of the very constitution of modern Western philosophy as a hegemonic and security project, which turns its ethnic character into an emblem of universalism. Nothing illustrates this more vividly than the projection of the Enlightenment, both French and German, as universal, while effacing its ethnic features, as shown through the framework of the anthropology of philosophy. Without elaborating this argument further here (on which, see Ahmad 2017), suffice it to note that instead of respectfully and judiciously taking from all, Western philosophy presented its own particularity (as universal) to all.

The description of thoughts of Rorty, Habermas and others as philosophical nationalism, some may have noticed, echoes Derrida's (1992: $10,2000)$ reflection that 'the claim of nationalism does not happen to philosophy by chance or from the outside, it is essentially and thoroughly philosophical.' What this reflection unveils, then, is a paradox: philosophy's assumption of its universality and its situatedness in a particular language, tradition and culture. Rather than resolve it, Derrida took it as the very condition of the possibility of philosophy. The formulation made above-for a universal philosophy proper to itself, the benchmark of to all must be preceded by from all-is one response to the paradox. 


\section{Imagining Alternatives to Nationalism}

Unlike Rorty and Habermas, who philosophize more with a banner (of nationalism) than with a hammer, as Nietzsche (1998) would have it (see next chapter), Appadurai has written explicitly and productively against nationalism. He begins one essay with 'we need to think ourselves beyond the nation.' This need is partly driven by biography. His father, a journalist with Reuters in Bangkok, met Subhas Chandra Bose (b. 1897), a towering Indian nationalist. Earlier linked to the Congress party led by Jawaharlal Nehru and Mohandas Gandhi, Bose, who believed in the use of violence to oust colonial rule, later formed his own movement. In WWII, he backed the Japanese, with whose support Bose formed an Indian government in exile. Appadurai's father was a minister of propaganda in that government. When Bose was killed or died in 1945 (some think he is still alive), he returned to India, where partisans of Bose became 'poor cousins' in the saga of India's nationalism. To the triumphant nationalism in power, they were 'unwelcome,' 'rouge nationalists,' 'an embarrassment.' The tale of Appadurai's father and his own experience in 'the elite sectors' of Bombay ignited his own 'doubts about patriotism' (1993: 411, 413, 412). Harrowing is thus the experience of the Appadurai family at the hands of anti-Bose nationalists. However, for many reasons, the 'embarrassed' remained part of the nationalist 'family,' albeit as its 'poor cousins.' By virtue of this, the embarrassment rings mostly honorific. It is time to script doubts about nationalism by those defined as 'anti-national' and perennial others of the family of nationalism at large. Not only are anti-nationals outside nationalism's family, they are not even a neighbour-and if they are, it is a neighbour who from the forced 'outside' has sneaked inside the family during the thick darkness of the night. Wilders construed the dynamic of nationalism, family and neighbour as follows: 'It [Turkey] is a very respected ally within NATO.... But I believe it is not a member of the family. A good neighbour is not the same as being a member of the family' (in Ahmad 2013: 247). Along with what seems honorific, can there be theoretical space for what is horrific? 
Given our unremarkable biographies, it is relevant to note only this. As a child, while going to the madrassa in his village in India, which meant passing through a Hindu quarter, its residents frequently hurled a rhymed taunt against Ahmad. Uttered in the local dialect, it asked:

Mīyāñ țīyāñ garī kē pahīyā

Mārab lāt ta jaiha kahīyā
O, you Muslim, like the wheel of a cart

When I kick you, where will you go/reach?

While the word mìyañ used by an outgroup to refer to Muslims is itself derogatory, its conjunctional echo word, tịyān (created through duplication by distorting the former it is positioned after), increases the viciousness of the taunt. ${ }^{16}$ Clearly, the question mark about the spatial location or belonging of Muslims in the last line nullifies any membership of the family and not even the status of a neighbour, let alone a good one. The question's infinite nature (dis)places Muslims anywhere and thereby nowhere. The threat of expulsion in the taunt is as certain as its destination is uncertain or unmarked. This was nationalism in a village with only dirt roads and without electricity - a village that in Ashis Nandy's ideation would otherwise likely qualify as the bastion of 'indigenous' (read Hindu) tolerance!

To return to Appadurai, in addition to slices of biography enabling him to see nationalism as 'the last refuge of ethnic totalitarianism,' bloodshed in the name of the nation, the rise in xenophobia in many parts of the world and so on are other factors to think about beyond the nation form. Who, then, are the agents of what he calls a 'postnational world'? Appadurai's focus is on the diaspora, whose lives are discordant with nationalism and its sovereignty. He discusses transnational networks and movements like the violent Khalistan movement, Amnesty International and Oxfam. The postnational mobile actors are thus business elites, UN soldiers and development specialists, as well as the laity. What interests Appadurai most are disjunctures (marked by technology and deterritorialization), not conjunctions, among space, place, citizenship and nationhood. To him, the US, already 'a postnational space,' is well suited to playing a pivotal role 'in the cultural politics of a postnational world,' where sovereignty too is postnational (1993: 419-421, 423, 427, 1996b: 58, 48, 43-44, 1998: 449). 
A full engagement with other rich aspects of Appadurai's complex writing is not feasible here, nor is it relevant to elaborate on the fact that part of his argument and its force, including his predictions, proved incorrect-something he himself recognized later (2006). ${ }^{17}$ Pertinent here is the fact that the locational source of his postnational world is essentially the present of the post-WWII era. In contrast, we close this section by discussing Muslim thinkers-India's poet-philosopher Iqbal and Egypt's Banna - who criticized the nation form before its total institutionalization. We posit that the debate on the postnational will benefit comparatively from the 'anti-national' Muslim thinkers' pre-national imaginations of a polis different from the nation form, as it would from a treatment of pre-WWII imaginations of the non-nation form in French West Africa (see next chapter). Since Islam was the language of their critique, and the Caliphate was the model they often appealed to, secularist dismissal of them as 'theocratic' will not do. This dismissal is more a supra-academic assault than a scholarly argument. Without going into the critical literature on the secular (e.g., see Asad 1999, 2003; van der Veer 2001), suffice it to note that the secular as supposedly separate from and the obverse of the religious, indeed of the 'sectarian' ${ }^{18}$ too (Abillama 2013), is also a weapon wielded by modern power. Under the pretext of fighting 'terrorism' and 'separatism,' the almost sacral deployment of laïcité by President Emmanuel Macron (and his predecessors too) illustrates this dynamic. His government's practice of stigmatizing subalternated French Muslims and denying them their religious rights (Fernando 2021; Gabon 2021; Ramdani 2021) goes against the idea of secularism as guaranteeing religious liberty to the faith minorities (van der Veer 2013b: 660).

To make sense of Muslim thinkers' pre-WWII anti- or non-national imaginations, we begin with a 2014 tweet by the Islamic State of Iraq and al-Sham (ISIS). Defying the national borders between Iraq and Syria, ISIS announced 'the end of Sykes-Picot.' Sykes and Picot are the last names of Mark Sykes and François Georges-Picot, diplomats respectively of Britain and France. Secretly agreed in 1916 (Falk 2015), the SykesPicot Agreement between Britain and France served as the basis for creating a number of nation states out of what had been the Ottoman Empire. That is, the creation of these new nation states did not take place by 
echoing the people's will, but rather in 'defiant opposition to the vast majority' (Farouk-Alli 2014: 8). One example typifies the imposition of the nation state as a colonial form of polis in the Middle East, itself an imperial term coined by an American naval officer, Alfred Mahan (Ahmad 2011). At his coronation as the King of Iraq in 1920, Faisal I, the third son of Sharif Husayn (amir of Mecca) who had earlier been handpicked by the British as the ruler of Syria, no Iraqi national anthem could be played because it did not exist. In the presence of the British officials, the band therefore played the anthem of the British crown, 'God save the King,' instead (Cleveland and Bunton 2009: 207; Allawi 2014: 380). Enacting the divide et impera policy, a British official stated: 'What we want is not a united Arabia, but a weak and disunited Arabia, split up into little principalities so far as possible under our suzerainty-but incapable of coordinated action against us' (in Curtis 2018).

In the opening scene of the ISIS video that was embedded in its tweet, the camera shows the Iraq-Syria border, described it as 'the so-called border of Sykes-Picot.' The central figure in the fifteen-minute video is its unnamed narrator, who, according to the Belfast Telegraph (2014), is from Chile. He asserts that 'we do not recognize it [the border].' With a gun hanging from his shoulder and a baseball cap on top of his flowing hair, he appears calm, and occasionally he also smiles. In fluent English, the narration is interspersed with Arabic phrases like 'praise be to God.' Pointing to the Iraqi national flag, he calls it 'flag of shirk [polytheism].' He then quotes Prophet Muhammad to say, 'Whoever calls to nationality, he is not from me.' The narrator describes ISIS's leader Abu Bakar Baghdadi simultaneously as a caliph and as 'the breaker of barriers,' resolving that we will 'break the borders of Iraq, Jordan, Lebanon and other countries also' because 'there is no nationality [in Islam].'

As it is evident, the ISIS video is preoccupied with first highlighting the Sykes-Picot nation-state border and then announcing its abolition. The reason for its abolition is grounded in a prophetic saying and Islam, which it interprets as standing above nationality and national barriers. It is after explaining this rationale that the narrator describes Baghdadi as a caliph and 'the breaker of barriers.' By virtue of the whole political matrix in which Baghdadi is called a caliph and the unilateral declaration of ISIS's Caliphate occurs, the very meanings of 'caliph' and 'caliphate' in 
2014 depart from their usage in the 1920s when, for instance, Indian Muslims (and Hindus) opposed the abolition of the Caliphate. At that time, the nation states had not come into being yet. Likewise, the meaning of Caliphate in 2014 differed from that in the eighteenth century or earlier when as an institution it existed, rather than only in its imagination by ISIS. The novel meaning of ISIS's Caliphate is further evident from the fact that it was announced after over six decades of relentless experiment with the nation state. That the alliance of local, regional and Western elites catalysing the brutal coup against the first democratically elected President of Egypt, Mouhammed Morsi, served as a prelude to ISIS's declaration is obvious. As for ISIS's deployment of religion, it bears a striking similarity with Christianity interpreted as the motor of a united Europe. Warning against the nationalist passions of European states against one another, in his 1922 German text, Pan-Europa, intellectual Richard von Coudenhov-Kalergi affirmed: 'Europe is bound together by the Christian religion, European science, art and culture, which rest on a Christian-Hellenic basis' (in Villanueva 2005: 74). To appreciate Coudenhov-Kalergi's thinking in its fullness is to recall, as cited earlier, Fredrick Schlegel's rendition of the Occident as coterminous with Christianity. It is, therefore, unsurprising that after WWII, with the support of the Vatican, devout Catholics like Konrad Adenauer, Robert Schuman and Alcide de Gasperi led the project of European integration. While it is true that Catholics have rallied for the EU cause more than Protestants, compared to nominal adherents in each, the devout among them both are the more vocal supporters of the EU (Nelsen et al. 2002).

There is some debate about the degree to which ISIS belongs properly to the fold of Islam. Fatwas have indeed been issued by several ulema against ISIS. Some have even called ISIS khāriji (see Anjum 2016; Sayyid 2017; Sing 2016). Setting the doctrinal debate aside, concerned as we are with the Muslim political imagination, it is our contention that ISIS's reading of the nation form has some precedence.

When, aged 22, al-Banna, a schoolteacher, founded the Society of Brotherhood in 1928, the fundamental challenge Egypt faced, as did the rest of the non-Western world, was European domination. Of the many responses to that domination, modernism was one. Against the country's modernist-secularist and wealthy elite, who, awed by the West's 
domination, had cheerfully adopted European manners as well, Banna equally opposed their politics of nationalism. Unlike those elites who were elated by the abolition of the Caliphate in 1924 by Mustafa Kemal Ataturk, for Banna it was a shock (Commins 1994). The goal of decolonization, as Banna saw it, was not simply national independence through the very institution of the nation state overtaken and continued by secular nationalists, it was also a moral-political independence the wellspring of which was Islam. That is not to say that he dismissed Egypt's ancient cultural heritage. Banna's main opposition was to the territorial bases of politics as the form of the nation and its inherent racism in modern Western political developments beyond Europe. Describing 'all racial or ancestral distinctions' as 'false,' he stressed the Qur'ānic idea of the single brotherhood of all believers as follows: 'Remember: Islam neither admits geographical differences; nor gives any importance to racial or blood distinctions ... it takes all the Muslim countries as one nation, although there may be great distances between them' (in Gani 2019: 660). Banna was emphatic that 'the Muslim Brothers do not ... advocate Pharaonism, Arabism, Phoenicianism, or Syrianism' (in Samman 2011: 181). When told that his idea of the community went against the reality of the modern age, with its 'prejudices of race and colour,' Banna remarked that the duty of the physician was not 'to agree with the patients,' but to 'treat them' and 'show the correct path.' Such was Banna's critique of the nation form against which he idealized the Caliphate in which geography, race or sheer birth were not the basis of collective life. In his view, Muslims should work to think about the Caliphate as an alternative mode of political life, rather than meekly mimic nationalism imported from the West. Marking the decolonial force of Banna's thought, Jasmine Gani (2019: 661, 667), however, observes how his organization subsequently developed 'strong nationalist overtones. ${ }^{19}$

Unlike Banna, who formed an organization, the poet-philosopher Iqbal built none. But his critique of nationalism was total and philosophically grounded. Educated at Trinity College Cambridge and with a doctoral degree from Germany's Munich University (see Fig. 1.2), ${ }^{20}$ he was an ardent and critical student of European thought. Rooted in Islamic philosophy, he was attracted by and studied the thoughts of such diverse thinkers and philosophers as Bergson, Hegel, Goethe, Milton, Nietzsche 


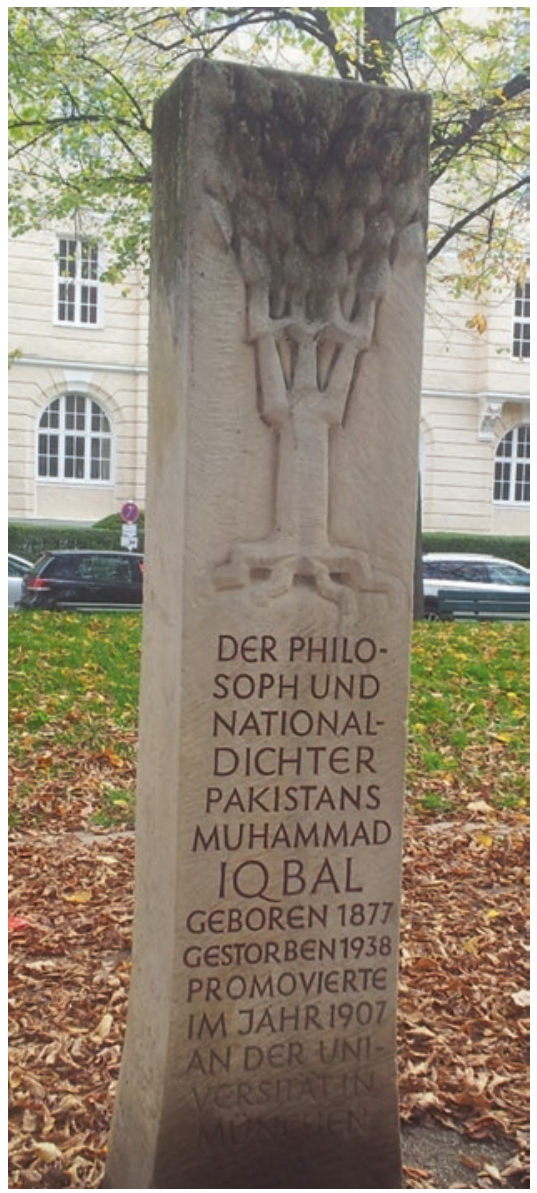

Fig. 1.2 A stele in Habsburg platz, Munich, marking the award of doctorate by Munich University to Iqbal in 1907. Wrongly, it describes lqbal as 'Pakistan's national poet' (see note 20). (Photo: Irfan Ahmad)

and Wordsworth. He also had personal-intellectual relations with many European thinkers, among them Edward John Thompson (1886-1946), an academic-missionary based in India (whose son was the British historian E.P. Thompson). Iqbal's rejection of territorial nationalism, the differentia specifica of which he took as its 'over-organized and homogenizing state structure,' was epistemological, not only political. Unlike 
nationalists concerned to prove to the West that their country was also a nation, Iqbal held that transplanting the institutional arm of Western politics, the nation form, in the colonized world would defeat any genuine decolonization. For precisely this reason, he viewed his resistance to nationalism as integral to his anti-imperialism. This was an unorthodox gesture, for in the then dominant discourse nationalism was seen as a rival to imperialism. As an anthropologist of European philosophy and politics, Iqbal was aware of the diversity within the West. He observed that, while European leaders were determined to shape the world by imposing the nation form, many of its thinkers had critiqued nationalism. It is unlikely that Iqbal did not know the works of Lord Acton (d. 1902), a Fellow at Trinity, who viewed Catholicism and nationalism as incompatible. Acton also feared the subduing of religion by the allencompassing nation state. Crucially, for Iqbal, nationalism in Europe had eclipsed the universal ethical message of Christ. Appreciative of Luther's critique of the ecclesiastical establishment, Iqbal, however, noted how the post-Luther era witnessed territorial-national wars and an upsurge in the growth of narrow loyalties (Sevea 2012: 130n14, 127, 131, 144).

If for Nietzsche (1998: 38) alcohol and Christianity were 'the two great European narcotics,' for Iqbal, nationalism and Western civilization were the 'narcotics of imperialism.' Elsewhere he likened nation states to idols (Sevea 2012: 135, 139). As the nature of Iqbal's philosophical hatred for the nation form is complex and space does not allow us to describe it in full, we can only explain some elements of it. Cognizant of Muslims inhabiting many spaces as the qaum, in his view, the qaum cannot trump affiliation to the millat, which signifies religion as a way of life. That was why he contested Husain Ahmad Madani (who was aligned with the Congress and its territorial nationalism), who, he held, privileged qaum over millat. But why millat over qaum? Iqbal did not want to leave the formation and development of selfhood ( $\mathrm{khudi})$ at the mercy of 'monocultural and territorially defined nation-state' (Sevea 2012: 162). Commentators on Iqbal often take his two poems, The Secrets of the Self and Mystery of Selflessness, as antithetical, the former stressing the individual, the latter the social. However, Iqbal Singh Sevea, whose exceptional work I draw on, aptly observes that Iqbal's notion of $k h u d \bar{\imath}$ (self) 
and bẹkhudì (selflessness) were complimentary, pertaining as they did more to the realm of millat than to qaum. Notably, Iqbal viewed nationalism as inimically pitting one segment of humanity against another. In 1936, two years before his death, he published his poetic anthology, Zarb-e-kalim (The Staff of Moses). Its subtitle was 'declaration of war against the contemporary age.' In a poem entitled 'Mecca and Geneva,' he called into question the very principles on which the League of Nations was founded. He deeply lamented the effacement of the 'unity of Adam, vahdat-e-adam' in an age when nation state had become the norm of global politics. Iqbal (1936: 54) concluded the poem by asking:

Mecca has dispatched a message to Geneva [the League of Nations' headquarters]

Should there be a unity of humankind or unity among nation-states?

So much for Iqbal's critique of the nation form! Did he imagine a form of polis alternative to the nation state? He did. In an earlier formulation-like most philosophers', his thoughts too evolved-he imagined India as a garden: 'we are its [India's] nightingales' and India is our garden, gulsetān. What symbolizes gulsetān is the diversity of flowers and plants, each with its autonomous self, each with its distinct colour and fragrance. Notable is Iqbal's depiction of garden's dwellers not as citizens but as nightingales. The flight, movement and song of the nightingales do not stop, like the affiliation and life forms of members of millat, at the borders of the nation states. In a monumental irony, the nation state of Pakistan abducted Iqbal as its ideologue even though he had died as a non-nationalist Indian, long before Pakistan's birth (see note 20).

In 2018, the former British Prime Minister, Tony Blair predicated the rise of three giant powers in the future: China, India and the West. Imagining that scenario, he pleaded that 'in those circumstances, we need the West to stay strong' and that 'Europe will be significantly weaker if you pull Britain out of Europe' (in Hunt 2018). When liberated from its Schmittean-like posturing in the naked game of power reduced to strategic interests and purged of morality, and if ethically cleansed of racism and Islamophobia by figures like Wilders and Le Pen, the EU is already a garden - a beautiful one. A recent essay, 'Who Wants the Caliphate?' by 
Ovamir Anjum (2019), a well-known American scholar of Islam, has generated much debate. Stating that democracy is not hostile to the Caliphate, in a discussion of his essay, Anjum (2021) imagined a Caliphate akin to the European Union.

\section{Outline of Chapters}

Considering developments in Ukraine and the likely break-up of the UK, Niccolo Caldararo (2014: 1) recently remarked that existing theories of the nation state were 'in trouble.' Earlier too, anthropologists had issued calls for new theorizing about nations and nationalism (Gingrich and Banks 2006: 21-23). New theories, even middle-range ones, however, are not on the horizon, at least not yet. Developing a new theory is not the avowed objective of this volume. In addition to the three arguments advanced in the Introduction, however, this volume will serve as a major springboard for achieving that goal for the following reasons. In-depth ethnographic accounts of nationalism in different parts of the world are essential to any sound theorizing. With a few exceptions, most of the chapters in this volume are based on long-term fieldwork, and all the contributors are trained anthropologists. Additionally, the distinction of this volume lies in the fact that unlike the earlier volume edited by Gingrich and Banks, it focuses on the non-Western world, covering many regions (Asia, Africa, the Middle East and partly Europe as well) and nation states such as China, Germany, India, Iran, Pakistan, South Africa and the Netherlands. The contribution, for example, by Verkaaik travels between Pakistan and the Netherlands. In line with earlier works on Asia such as those by Kapferer (1988) and Tambiah (1997), this volume discusses nations and nationalism in a multi-dimensional and globally comparative way.

In marked contrast to the volume by Gingrich and Banks, this one is not premised on neatly demarcating new nationalism or neo-nationalism from the old one. That is not to say that we take nationalism to be a static phenomenon or maintain that nationalist mobilizations and their discursive articulations have remained the same over the long term. A common analytical hazard in formulas such as the suffix 'neo,' however, is that in outlining the contours and properties of 'neo-nationalism,' it may end up 
reifying both the old and the new, thereby precluding a proper treatment of vital elements of continuity. In ways more than one, Mukulika Banerjee's account of Indian/Hindu nationalism (in Gingrich and Banks) illustrates this hazard (see Ahmad and van der Veer, this volume). The observation by Tariq Modood (2019: 233), a noted British scholar of nationalism and multiculturalism, thus seems pertinent, namely that 'today's "new nationalism" marks merely the latest iteration of yesterday's old nationalism.' Put differently, following critiques by Prasenjit Duara (1993) and van der Veer (1994) of Benedict Anderson's (1991) account of nationalism premised on a sharp rupture between the traditional and the modern, the past and the present, we maintain that a more fertile way is to see them relationally and dynamically (van der Veer 2013a).

What distinguishes this volume is also its distinct themes. Though attentive to politics in the realm of the state or party politics, it discusses at length social-cultural processes like urban migration $(\mathrm{He})$, rituals of animal sacrifice and prayer (Tayob, Yu), music (van der Linden), the salience of the media and cultural translation in the imagination of the nation form (de Kloet), e-commerce through digital platforms and the Internet (Lengen) and Islamophobia among Chinese Christian revivalists (Kang). Likewise, it dwells as much on the functioning and ideology of secularism (Ahmad and van der Veer), the imbrication between literature, nation and secularity (Verkaaik), as it does on atheism and its impossibility (Binder). Obviously, in many cases these themes overlap as well. The majority of the chapters richly and variously deal with the subject of religion-African religious practices, Chinese religions, Christianity, Hinduism and Islam. And they do by taking up a multiplicity of issues in diverse sites: Ahmad and van der Veer on India (Christianity, Hinduism and Islam); Alinejad on Iran (Shiism); Binder on Southern India (Hinduism and atheism); Kang on China (Christianity); Tayob on South Africa (Islam, African religious practices); van der Linden on India (Hinduism and Islam); and Yu on Germany (Christianity). The thematic diversity demonstrated in the various contributions is as important as are the regional or geographical social-political formations around which the chapters are organized. As for the framework, like the diversity of themes broached in the various chapters, it is far from uniform. Many contributors draw on more than one theoretical tradition. While most 
contributions are academic in a conventional sense, the chapter by Alinejad appears to be informed by the concerns of the policy-security field. Echoing anthropology's foundational goals, a comparative approach informs descriptions as well as analyses in many contributions, though some chapters do it more rigorously than others do.

Finally, a key distinguishing feature of the volume is that, in their analyses and arguments, most contributors draw differently on Peter van der Veer's enormously rich and theoretically significant scholarship on religion and nationalism. Crucial aspects of his scholarship that most contributors find salutary are: the continuing significance of religion and its entwining with nationalism (van der Veer 1994), the methodological renewal of anthropology as a comparative pursuit (van der Veer 2016) and the fruitful formulation for studying cultural and religious formations vis-à-vis nationalism in the West and in the non-West not as autonomous but in historically dense interactions with each other (van der Veer 2001). This historical sensibility is manifested in various ways in his works, the latest of which connects the 2015 European refugee crisis to the era of the Reformation (2021).

Such are the aims and distinct theoretical and methodological contours of The Nation Form in the Global Age. It is only appropriate, then, that readers first know the range and depth of Peter van der Veer's corpus of scholarly works as an anthropologist. This is the task of the next chapter, which, by weaving his academic biography and relevant snippets of his non-academic life together, outlines the oeuvre of Peter van der Veer.

Acknowledgements We thank Rizwan Ahmad (linguist), Patrice Ladwig and Sanam Roohi (both anthropologists) and Mahjoob Zweiri (historian of the Middle East) for their useful and critical comments on an earlier draft. To Talal Asad, we are grateful for our discussion on nationalism, especially its dynamics in the Middle East. The usual disclaimer applies. 


\section{Notes}

1. In different ways and from varied standpoints, scholars have argued over and prophesied the decline, even the end, of the nation state. Others have made counterarguments about its continuation. For these diverse positions, see Appadurai (1996a), Benhabib (2009), Guehenno (1995), Habermas (2003), Harris (2016), Mann (2003), Smith (2007) and Strange (2003).

2. Respectively, Gebrekidan and Apuzzo (2021), Bollyky and Bown (2020) and Ghebreyesus (2021).

3. On the decolonization of knowledge, a recent but growing field, see Hallaq (2018) and Mignolo (2002, 2009); on decolonizing anthropology, see Harrison (1997), Smith (1999) and Ahmad (2021a).

4. See Boyer and Lomnitz (2005), Herzfeld (2016), Gingrich and Banks (2006) and Smith (2007). The cited literature is only representative. With an overview of major works on nationalism, but with hardly any signposts to an alternative to nationalism, Herzfeld arranged his bibliographical essay under ten heads: nationalism under construction, nationalisms in conflict, the status quo, emergent nationalisms, archaeology and nationalism, folklore and national culture, language and discourse, heritage, performance and eugenics. We do not reference the standard anthropological and other works, which are discussed, among others, by Herzfeld, van der Veer (1994, 2013b), Breuilly (2013) and others. On nationalism and the visual arts, see the latest and interesting work by Karaca (2021); see also note 12. For an overview of social theories of nationalism, see Delanty and O'Mahony (2002).

5. Much of the logic, among the Hindu elite and the public alike, against the vilification of Islam and glorification of Hinduism as the core of the Hindu nation stems from the British-Orientalist idea of Islam as external and Hinduism as indigenous to India. Against this Orientalist-nationalist notion, van der Veer (2013b: 665) observes: 'To see Hinduism as indigenous one needs to abolish the idea that it has been a creation of Aryan invaders, members of Indio-European family; and to see Islam and Christianity as alien one has to ignore their millennial or even longer presence on Indian soil.'

6. Every state has some kind of formula for an internal enemy too (Schmitt 1996). 
7. To single out Donald Trump for the construction of border walls, which he called 'big, beautiful,' is at best convenient. Joe Biden has not stopped it; see Graziosi (2021).

8. In Charles Tilly's (1975: 42) formulation, 'war made the state, and the state made war.'

9. In an ethnographic study discussing Muslim immigrants and refugees (from Somalia) in Tilburg, Paul Mutsaers (2014) describes the installation and working of 'borders' within the Netherlands (and the EU).

10. In one study, around 50 per cent of Americans are 'occasionally mentally disturbed' (Greenfeld 2016a: 122). Mental illness as an official medical problem in non-Western countries is relatively recent, reported cases being fewer than in industrialized nation states.

11. Though signed by both Habermas and Derrida, the text is composed mainly by the former; see Ahmad (2021b: vii-note 5).

12. In her fine work, Karaca $(2021: 41,42,4)$ compares German and Turkish nationalisms in the field of the visual arts. She writes that German artists viewed France as a 'foreign' civilization and that the projection of German art 'as European art in a western tradition' took place in the process of 'recivilizing Germany'-indeed 'occidentalizing' it-after WWII. Based on extensive ethnographic work, Karaca argues that despite globalization and the dominant understanding of art as 'universal,' it is the national frame that 'continues to refract the production and perception of art.'

13. A host of American intellectuals, most of them top academics who included teachers of ethics and religion, supported the GWOT in the name of Enlightenment values (van der Veer 2004: 12).

14. Also, see Canovan (2000), Gomberg (1990), Hayward (2007) and Viroli (1997). Smart (1998: 84) puts it succinctly: 'However nicely phrased, patriotism implies the practical inferiority of others.'

15. Habermas' (1998: 399) account is markedly Weberian. He draws on Weber's 'the ideal-typical model' and mostly works with his definition of the state. From the perspective of the argument in the Introduction, the commonality of nationalism between the two is striking; Weber 'was an unabashed German nationalist' (Lebow 2017a: 2). Habermas' reliance on Weber's definition of the state as the sole power with a monopoly of the legitimate use of violence within a demarcated territory neglects the fact that Weber noted the great states imposing their ambition on other states. This was manifest in Weber's concerns about defending Germany's 
distinct future and culture from the threat from Russians and 'Englishspeaking "society" (in Lebow 2017b: 17).

16. I thank the linguist Rizwan Ahmad for clarifying its socio-linguistic dimensions.

17. The 2019 Citizenship Amendment Act, based on the ethnic idea of a Hindu nation (Ahmad 2020b), demonstrates reterritorialization more than de-territorialization.

18. The vulgate of the 'sectarian' Middle East, given wider currency since the launch of the GWOT, is surely a 'reality.' However, this reality cannot be understood, as historian Makdisi (2017: 4) rightly observes, without taking sectarianism as a 'colonial strategy of governance insofar as Britain, France, Israel, and the United States have routinely manipulated the religious and ethnic diversity of the region to suit their own imperial ends.' Integral to Orientalist repertoire, sectarianism is tied directly to the logic of nation-state formation. With much finesse, Al-Eriani (2020) shows how the Western powers explained the failed 2011 democratic uprising in Yemen in terms of 'sectarian conflict.' The descriptor 'sectarian Middle East' also effaces the supra-sectarian intellectual and political initiatives (Ahmad 2015: 101).

19. Cf. Asad (1999: 191), who, while observing that Islamists are preoccupied with nation states, maintains that they are still different because they do not have the same commitment to nationalism as secular nationalists have and that commitment of the former is not teleologically driven. This difference exists in another respect. Clearly, imagination is at work in the thought of Banna as it is in the thoughts of nationalists. For example, Hindu nationalists imagine the past as showing that India was already a nation, while Banna and others read the past to reach a different, opposite conclusion. On approaching pre-modern possibilities, see Scott (1999). The construction of 5000 years of the nation's glorious past by India, China, Iran or other states is mythical as it is xenophobic-racist, the latter being most eloquently evident in the powerful myth of Iran as an Aryan nation officially staged by the secularmodern king of Iran, the Shah (see Alinejad, this volume).

20. It is ironic that the poet-philosopher who railed against the territorial nation state is posthumously called Pakistan's 'national' poet. This description itself belongs to nationalism connecting Germany and the Subcontinent. Given that Iqbal died nearly a decade before Pakistan's birth, what makes him a Pakistani? Obviously, Pakistani nationalism 
hijacked Iqbal to legitimize itself. Unsure if Munich's municipal office decided the stele's text, describing Iqbal as 'Indian-Pakistani' by scholars like Andrew March (2019: 77) may seem awkward.

\section{References}

Abillama, Raja. 2013. The Sectarian as a Category of Secular Power. In Essays on Religion and Violence, ed. Bryan Turner, 145-162. New York: Anthem. Ahmad, Irfan. 2011. The Categorical Revolution: Democratic Uprising in the Middle East. Economic and Political Weekly 46 (45): 30-35.

- 2013. In Defense of Ho(s)tel: Islamophobia, Domophilia and the West. Politics, Religion \& Ideology 14 (2): 234-252. . 2015. On the State of the (Im)possible: Notes on Wael Hallaq's Thesis. Journal of Religious and Political Practice 1 (1): 97-106. . 2017. Religion as Critique: Islamic Critical Thinking from Mecca to the Marketplace. Chapel Hill, NC: University of North Carolina Press. . 2018. Is Political Anthropology Dead? Anthropology News, 26 February. https://anthrosource.onlinelibrary.wiley.com/doi/10.1111/AN.784 - 2019. Introduction: Democracy and the Algebra of Warfare-Welfare. In The Algebra of Warfare-Welfare: A Long View of India's 2014 Election, ed. Irfan Ahmad and Pralay Kanungo, 1-55. New Delhi: Oxford University Press. - 2020a. Coronavirus, Naked Life and the Importance of Giorgio Agamben. The Polis Project, 25 May.

. 2020b. Citizen Amendment Act is Confirmation of India as a Hindu Nation-State. Berkeley Center for Peace, Religion and World Affairs, Georgetown University. 9 March.

—. 2021a. Terrorism in Question: Toward a Decolonial Anthropology. Under review with the University of Chicago Press.

. 2021b. Foreword: Scholarship on Populism, Populism in Scholarship.

In Nicholas Morieson's Religion and the Populist Radical Right, v-ix (see Morieson).

Alemanno, Alberto. 2020. We Lived the European Dream. Will any Politician Stand up for Open Borders? The Guardian, 22 May.

Al-Eriani, Kamilia. 2020. Secularism, Security and the Weak State: Dedemocratizing the 2011 Yemeni Uprising. Interventions: International Journal of Postcolonial Studies. https://doi.org/10.1080/1369801X.2020.1816854. 
Allawi, Ali. 2014. Faisal I of Iraq. New Haven: Yale University Press. Allen, Kieran. 2004. Max Weber: A Critical Introduction. London: Pluto.

Anderson, Benedict. 1991. Imagined Communities: Reflections on the Origins and Spread of Nationalism. London: Verso.

Anjum, Ovamir. 2016. ISIS \& the Future of Islam. Talk at Georgetown University. https://www.youtube.com/watch?v=L3HU5vUHRYo 2019. Who Wants the Caliphate? Yaqeen Institute, 31 October. https:// yaqeeninstitute.org/ovamiranjum/who-wants-the-caliphate

- 2021. The Caliphate and Its Meaning for Muslim Minorities. 13 April. https://www.youtube.com/watch?v=zKzM5xlwL-k

Appadurai, Arjun. 1993. Patriotism and Its Future. Public Culture 5: 411-429. -1996a. Modernity at Large: Cultural Dimensions of Globalization. Minneapolis: University of Minnesota Press.

- 1996b. Sovereignty without Territoriality: Notes for a Postnational Geography. In The Geography of Identity, ed. Patricia Yaeger, 40-58. Ann Arbor, MI: The University of Michigan Press.

$51(4): 1-8$.

-1998. Full Attachment. Public Culture 10 (2): 443-449.

- 2006. Fear of Small Numbers: An Essay on the Geography of Anger. Durham: Duke University Press.

Asad, Talal. 1999. Religion, Nation State, Secularism. In Nation and Religion.

Perspectives on Europe and Asia, ed. Peter van der Veer and Hartmut Lehmann,

178-196. Princeton: Princeton University Press.

- 2003. Formations of the Secular: Christianity, Islam, Modernity. Stanford:

Stanford University Press.

Belfast Telegraph. 2014. Video: Islamic State Media Branch Releases “The End of Sykes-Picot." 1 July.

Benhabib, Seyla. 2009. Cosmopolitanism and Democracy: Affinities and Tensions. The Hedgehog Review 11 (Fall): 30-41.

Billig, Michael. 1993. Nationalism and Richard Rorty: The Text as a Flag for Pax Americana. New Left Review November-December: 69-83.

Bollyky, Thomas, and Chad Bown. 2020. The Tragedy of Vaccine Nationalism. Foreign Affairs September/October: 96-108.

Boyer, Dominic, and Claudio Lomnitz. 2005. Intellectuals and Nationalism:

Anthropological Engagements. Annual Review of Anthropology 34: 105-120. Breuilly, John, ed. 2013. The Oxford Handbook of the History of Nationalism.

Oxford: Oxford University Press. 
Caldararo, Niccolo. 2014. Editorial: Anthropology and the Future of the Nation-State and Nationalism. Anthropology 2 (4): 1-2.

Canovan, Margaret. 2000. Patriotism is Not Enough. British Journal of Political Science 30 (3): 413-432.

Cederman, Lars-Erik, Andreas Wimmer, and Brian Min. 2010. Why Do Ethnic Groups Rebel? New Data and Analysis. World Politics 62 (1): 87-119.

Chambers, Simone. 1996. Reasonable Democracy: Jürgen Habermas and the Politics of Discourse. Ithaca: Cornell University Press.

Cleveland, William, and Martin Bunton. 2009. A History of the Modern Middle East. Philadelphia: Westview.

Commins, David. 1994. Hasan al-Banna (1906-1949). In Pioneers of Islamic Revival, ed. Ali Rahnema, 125-153. London: Zed.

Crawford, Neta, and Catherine Lutz. 2019 Human Costs of Post-9/11 Wars. 13 November. https://watson.brown.edu/costsofwar/files/cow/imce/papers/2019/ Direct\%20War\%20Deaths\%20COW\%20Estimate\%20November\%20 13\%202019\%20FINAL.pdf

Curtis, Mark. 2018. Why the West's World War One Carve-up is Still Unfinished Business. Middle East Eye, 29 November.

Delanty, Gerard, and Patrick O'Mahony. 2002. Nationalism and Social Theories: Modernity and the Recalcitrance of the Nation. London: Sage.

Derrida, Jacques. 1992. Onto-Theology of National-Humanism (Prolegomena to a Hypothesis). Oxford Literary Review 14 (1): 3-23.

2000. On His Concept of Deconstruction. https://www.sam-network. org/video/on-his-concept-of-deconstruction-part-4-4

Donnan, Hastings, Bjørn Thomassen, and Harald Wydra. 2018. The Political Anthropology of Borders and Territory: European Perspectives. In Handbook of Political Anthropology, ed. Harald Wydra and Bjørn Thomassen, 344-359. Cheltenham, UK: Elgar.

Duara, Prasenjit. 1993. De-Constructing the Chinese Nation. The Australian Journal of Chinese Affairs 30: 1-26.

Dunning, Tristan, and Damian Doyle. 2018. A Tragic Anniversary: The Costs of the Iraq Invasion. Australian Institute of International Affairs, 20 March.

DW News. 2021. Czech and Austrian Travelers Turned Away from German Borders. 15 February.

Eriksen, Thomas. 2001. Small Places, Large Issues: An Introduction to Social and Cultural Anthropology. 2nd ed. London: Pluto.

Falk, Richard. 2015. ISIS's Challenge to the Statist World Order. Middle East Eye, 16 December. 
Fanon, Franz. 1963. The Wretched of the Earth. Translated by Richard Philcox. New York: Grove.

Farouk-Alli, Aslam. 2014. Sectarianism in Alawi Syria: Exploring the Paradoxes of Politics and Religion. Journal of Muslim Minority Affairs 34 (3): 207-226. Fernandez, Belen. 2011. The Imperial Messenger: Thomas Friedman at Work. London: Verso.

Fernando, Mayanthi. 2021. Rinse and Repeat: French Secularism as Political Theater. Berkeley Center for Peace, Religion and World Affairs, Georgetown University. 13 May.

Gabon, Alain. 2021. Macron's Islamic Charter is an Unprecedented Attack on French Secularism. Middle East Eye, 3 February.

Gani, Jasmine. 2019. Escaping the Nation in the Middle East: A Doomed Project? Fanonian Decolonization and the Muslim Brotherhood. Interventions: International Journal of Postcolonial Studies 21 (5): 652-670.

Gebrekidan, Selam, and Matt Apuzzo. 2021. Rich Countries Signed Away a Chance to Vaccinate the World. The New York Times, 21 March.

Ghebreyesus, Tedros Adhanom. 2021. Vaccine Nationalism Harms Everyone and Protects No One. Foreign Policy, 2 February.

Gingrich, Andre, and Marcus Banks, eds. 2006. Neo-Nationalism in Europe and Beyond: Perspective from Social Anthropology. New York: Berghahn.

Gomberg, Paul. 1990. Patriotism is Like Racism. Ethics 101 (1): 144-150.

Graziosi, Graig. 2021. Construction of Trump's Border Wall May Continue under Biden, Administration Admits. The Independent, 7 April.

Greenfeld, Liah. 2016a. Advanced Introduction to Nationalism. Cheltenham, UK: Elgar.

2016b. Introduction: Collected Volume as an Experiment. In Globalization of Nationalism: The Motive Force behind the Twenty-First Century Politics, ed. Liah Greenfeld, xiii-xxviii. Colchester, UK: ECPR.

Gregory, Derek. 2004. The Colonial Present. Malden, MA: Blackwell.

Guehenno, Jean-Marie. 1995. The End of the Nation-State. Translated by Victoria Elliott. Minneapolis: University of Minnesota Press.

Habermas, Jürgen. 1998. The European Nation-State: On the Past and Future of Sovereignty and Citizenship. Public Culture 10 (2): 397-416.

- 2003. Making Sense of the EU: Toward a Cosmopolitan Europe. Journal of Democracy 14 (4): 86-100.

Habermas, Jürgen, and Jacques Derrida. 2003. February 15, or What Binds Europeans Together: A Plea for a Common Foreign Policy, Beginning in the Core of Europe (trans. Max Pensky). Constellation 10 (3): 291-297. 
Hall, John, and Siniša Malešević. 2013. Introduction: Wars and Nationalisms. In Nationalism and War, ed. John Hall and Siniša Malešević, 1-28. Cambridge: Cambridge University Press.

Hallaq, Wael. 2018. Restating Orientalism: A Critique of Modern Knowledge. New York: Columbia University Press.

Harris, Erika. 2016. Why has Nationalism Not Run its Course? Nations and Nationalism 22 (2): 243-247.

Harris, Marvin. 1991. Cultural Anthropology. 3rd ed. New York: Harper Collins. Harrison, Faye, ed. 1997. Decolonizing Anthropology: Moving Further Toward an Anthropology of Liberation. Arlington: Association of Black Anthropologists and American Anthropological Association.

Hayward, Clarissa Rile. 2007. Democracy's Identity Problem: Is “Constitutional Patriotism" the Answer? Constellations 14 (2): 182-196.

Herzfeld, Michael. 2016. Nationalism. Oxford Bibliographies. https://doi. org/10.1093/obo/9780199766567-001.

- 2018. Anthropological Realism in a Scientistic Age. Anthropological Theory 18 (1): 129-150.

Hill, Mike, and Warren Montag, eds. 2000. Masses, Classes, and the Public Sphere. London: Verso.

Hunt, Darren. 2018. Tony Blair makes SHOCKING Prediction of New World Order with THESE Three Superpowers. 14 December. https://www. express.co.uk/

Hutchinson, John. 2017. Nationalism and War. Oxford: Oxford University Press. Iqbal, Muhammad. 1936. Zarb-e-kalim. Lahore: Publisher Not Given.

Jones, Reece. 2012. Border Walls: Security and the War on Terror in the United States, India, and Israel. London: Zed.

Kapferer, Bruce. 1988. Legends of People, Myths of State: Violence, Intolerance, and Political Culture in Sri Lanka and Australia. Washington, DC: Smithsonian Institute Press.

Karaca, Banu. 2021. The National Frame: Art and State Violence in Turkey and Germany. Fordham University Press.

Koselleck, Reinhart. 1988 [1959]. Critique and Crisis: Enlightenment and Pathogenesis of Modern Society. Cambridge, MA: The MIT Press.

Kottack, Conrad. 2008. Anthropology: The Exploration of Human Diversity. 12th ed. Boston: McGraw Hill.

Krishnan, Murali. 2020. Coronavirus: "Chinese-looking” Indians Targeted in Racist Attacks. Deutsche Welle, 30 March. 
Kuper, Adam. 1983 [1973]. Anthropology and Anthropologist: The Modern British School. London: Routledge.

Lazarus, Neil. 1993. Disavowing Decolonization: Fanon, Nationalism, and the Problematic of Representation in Current Theories of Colonial Discourse. Research in African Literatures 24 (4): 69-98.

Lebow, Richard Ned. 2017a. Introduction. In Max Weber and International Relations, ed. Richard Lebow, 1-9. Cambridge: Cambridge University Press. . 2017b. Max Weber and International Relations. In Max Weber and International Relations, ed. Richard Lebow, 10-39. Cambridge: Cambridge University Press.

Liu, Andrew. 2020. Blaming China for Coronavirus isn't Just Dangerous. It Misses the Point. The Guardian, 10 April.

MacIntyre, Alasdair. 1984. Is Patriotism a Virtue?'The Lindley Lecture. University of Kansas Press.

Makdisi, Ussama. 2017. The Mythology of the Sectarian Middle East. https:// www.bakerinstitute.org/research/mythology-sectarian-middle-east/

Malešević, Siniša. 2013. Is Nationalism Intrinsically Violent? Nationalism and Ethnic Politics 19 (1): 12-37.

Malinowski, Bronislaw. 1941. An Anthropological Analysis of War. American Journal of Sociology 46 (4): 521-550.

- 1945. The Dynamics of Cultural Change. New Haven: Yale University Press.

Mann, Michael. 2003. Has Globalization Ended the Rise and Rise of the Nation-State? In The Global Transformations Reader: An Introduction to the Globalization Debate, ed. David Held and Anthony McGrew, 135-146. Cambridge: Polity.

March, Andrew. 2019. The Caliphate of Man: Popular Sovereignty in Modern Islamic Thought. Cambridge, MA: The Belknap Press of Harvard University Press.

Marvin, Carolyn. 2002. A New Scholarly Dispensation for Civil Religion. Journal of Communication and Religion 25 (1): 21-33.

Marvin, Carolyn, and David Ingle. 1999. Blood Sacrifice and the Nation: Totem Rituals and the American Flag. Cambridge: Cambridge University Press.

Marx, Anthony. 2003. Faith in Nation: Exclusionary Origins of Nationalism. Oxford: Oxford University Press.

Mignolo, Walter. 2002. The Geopolitics of Knowledge and Colonial Difference. South Atlantic Quarterly 101 (1): 57-96. 
- 2009. Epistemic Disobedience, Independent Thought and Decolonial Freedom. Theory, Culture \& Society 26 (7-8): 159-181.

Mills, C. Wright. 1959. The Sociological Imagination. New York: Oxford University Press.

Mitchell, Joshua. 2008. Religion and the Fable of Liberalism: The Case of Hobbes. Theoria 55 (1): 1-16.

Modood, Tariq. 2019. A Multicultural Nationalism? Brown Journal of World Affairs 25 (2): 233-246.

Morieson, Nicholas. 2021. Religion and the Populist Radical Right: Secular Christianism and Populism in Western Europe. Wilmington: Vernon Press.

Müller, Jan-Werner, and Kim Lane Scheppele. 2008. Constitutional Patriotism: An Introduction. International Journal of Constitutional Law 6 (1): 67-71.

Murti, Kamakshi. 2001. India: The Seductive and the Seduced 'Other' of German Orientalism. Westport: Greenwood Press.

Mutsaers, Paul. 2014. An Ethnographic Study of the Policing of Internal Borders in the Netherlands: Synergies Between Criminology and Anthropology. The British Journal of Criminology 54 (5): 831-848.

Nelsen, Brent, James Guth, and Cleveland Fraser. 2002. Does Religion Matter? Christianity and Public Support for the European Union. European Union Politics 2 (2): 191-217.

Nietzsche, Friedrich. 1998. Twilight of the Idols or How to Philosophize with a Hammer. Translated by Duncan Large. Oxford: Oxford University Press.

Parkin, David. 2007. Introduction: Emergence and Convergence. In Holistic Anthropology: Emergence and Convergence, ed. David Parkin and Stanley Ulijaszek, 1-20. London: Berghahn.

Polanyi, Karl. 1957 [1944]. The Great Transformation: The Political and Economic Origins of Our Time. Boston: Beacon.

Ramdani, Nabila. 2021. Macron's Anti-Muslim Fake News in the FT Needs Urgent Correcting. Middle East Eye, 13 April.

Roache, Madeline. 2021. A German Photographer Captures Ordinary People Adapting to Life Under Lockdown. Time, 30 April.

Rorty, Richard. 1998. Achieving Our Country. Leftist Thought in TwentiethCentury America. Cambridge, MA: Harvard University Press.

- 1999. Philosophy and Social Hope. London: Penguin.

Samman, Khaldoun. 2011. The Clash of Modernities: The Islamist Challenge to Arab, Jewish, and Turkish Nationalism. London: Routledge.

Sayyid, Salman. 2017. Political Islam in the Aftermath of "Islamic State". ReOrient 3 (1): 65-82. 
Schmitt, Carl. 1996. The Concept of the Political. Translated by George Schwab. Chicago: Chicago University Press.

Scott, David. 1999. Refashioning Futures: Criticism after Postcoloniality.

Princeton: Princeton University Press.

Sen, Jahnavi. 2021. Maha-Kumbh Mela Vs Tablighi Jamaat: Not Comparable, But Not For The Reasons Rawat Thinks. The Wire, 12 April.

Sevea, Iqbal Singh. 2012. The Political Philosophy of Muhammad Iqbal: Islam and Nationalism in Late Colonial India. Cambridge: Cambridge University Press. Sikander, Zainab. 2021. Silence on Kumbh Shows Indians Think only Muslims Spread Covid. The Print, 12 April.

Sing, Manfred. 2016. Dis/connecting Islam and Terror: the "Open Letter to Al-Baghdadi" and the Pitfalls of Condemning ISIS on Islamic Grounds. Journal of Religious and Political Practice 2 (3): 296-318.

Skalnik, Peter. 1983. Questioning the Concept of the State in Indigenous Africa. Social Dynamics 9 (2): 11-28.

Sloterdijk, Peter. 2012. The Space of Global Capitalism and its Imaginary Imperialism: An Interview with Peter Sloterdijk. In In Medias Res: Peter Sloterdijk's Spherological Poetics of Being Paperback, ed. Willem Schinkel and Liesbeth Noordegraaf-Eelens, 185-194. Amsterdam: Amsterdam University Press.

Smart, Ninian. 1998. Tradition, Retrospective Perception, Nationalism and Modernism. In Religion, Modernity and Postmodernity, ed. Paul Heelas, 79-87. Oxford: Blackwell.

Smith, Anthony. 2007. Nations in Decline? The Erosion and Persistence of Modern National Identities. In Nationalism in a Global Era: The Persistence of Nations, ed. Mitchell Young, Eric Zuelow, and Andreas Sturm, 16-29. London: Routledge.

Smith, Linda Tuhiwai. 1999. Decolonizing Methodologies: Research and Indigenous Peoples. London: Zed.

Sorkin, David. 2015. Religious Minorities and Citizenship in the Long Nineteenth Century: Some Contexts of Jewish Emancipation. In Politics of Religious Freedom, ed. Winnifred Sullivan, Elizabeth Hurd, Saba Mahmood, and Peter Danchin, 115-126. Chicago: University of Chicago Press.

Steger, Manfred. 2005. From Market Globalism to Imperial Globalism: Ideology and American Power after 9/11. Globalizations 2 (1): 31-46.

- 2009. From "We the People" to "We the Planet": Neoconservative Visions of a Global USA. In Politics of Globalization, ed. Samir Dasgupta, 65-81. Delhi: Sage. 
Strange, Susan. 2003. The Declining Authority of the States. In The Global Transformations Reader: An Introduction to the Globalization Debate, ed. David Held and Anthony McGrew, 127-134. Cambridge: Polity.

Tambiah, Stanley. 1997. Leveling Crowds: Ethnonationalist Conflicts and Collective Violence in South Asia. Berkeley: University of California Press.

TEDx Talks. 2020. Twins Unknown: Islamophobia and Domophilia | Prof. Dr. Irfan Ahmad| TEDxUniGoettingen. https:/www.youtube.com/ watch? $\mathrm{v}=\mathrm{UGrBiLS} 3 \mathrm{Bs} 8$

Theise, Philippe. 2021. France's Asian Community Fights Back against Racist Attacks during Pandemic. France24.com, 4 April.

Tilly, Charles. 1975. Reflections on the History of European State-making. In The Formation of National States in Western Europe, ed. Charles Tilly, 3-83. Princeton: Princeton University Press.

Turner, Bryan. 2004. Democracy in One Country? Reflections on Patriotism, Politics and Pragmatism. European Journal of Social Theory 7 (3): 275-289. van der Veer, Peter. 1994. Religious Nationalism: Hindus and Muslims in India. Berkeley: University of California Press.

. 1996. Writing Violence. In Contesting the Nation: Religion, Community, and the Politics of Democracy in India, ed. David Ludden, 250-269. Philadelphia: University of Pennsylvania Press.

- 2001. Imperial Encounters: Religion, Nation, and Empire. Princeton:

Princeton University Press.

2004. War Propaganda and Liberal Public Sphere. In Media, War and

Terrorism, ed. Peter van der Veer and Shoma Munshi, 9-21. London: Routledge Curzon.

. 2013a. The Modern Spirit of Asia: The Spiritual and the Secular in China and India. Princeton: Princeton University Press.

- 2013b. Nationalism and Religion. In The Oxford Handbook of the History of Nationalism, ed. John Breuilly, 655-671. Oxford: Oxford University Press.

. 2016. The Value of Comparison, Lewis Henry Morgan Lectures. Durham: Duke University Press.

- 2021. German Refugees and Refugees in Germany. In Refugees and Religion: Ethnographic Studies of Global Trajectories, ed. Birgit Meyer and Peter van der Veer, 34-47. London: Bloomsbury Academic.

Villanueva, Daniel. 2005. Richard von Coudenhov-Kalergi's "Pan-Europa” as the Elusive "Object of Longing". Rocky Mountain Review of Language and Literature 59 (2): 67-80. 
Viroli, Maurizio. 1997. For Love of Country: An Essay on Patriotism and Nationalism. Oxford: Clarendon.

Weber, Cynthia. 2010. International Relations Theory: A Critical Introduction. 3rd ed. London: Routledge.

Wimmer, Andreas. 2013. Waves of War: Nationalism, State Formation, and Ethnic Exclusion in the Modern World. Cambridge: Cambridge University Press.

Young, Iris. 2003. Europe and the Global South: Towards a Circle of Equality. Open Democracy, 19 August.

Open Access This chapter is licensed under the terms of the Creative Commons Attribution 4.0 International License (http://creativecommons.org/licenses/ by/4.0/), which permits use, sharing, adaptation, distribution and reproduction in any medium or format, as long as you give appropriate credit to the original author(s) and the source, provide a link to the Creative Commons licence and indicate if changes were made.

The images or other third party material in this chapter are included in the chapter's Creative Commons licence, unless indicated otherwise in a credit line to the material. If material is not included in the chapter's Creative Commons licence and your intended use is not permitted by statutory regulation or exceeds the permitted use, you will need to obtain permission directly from the copyright holder.

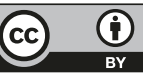

